"Beautifully written, relentlessly insightful, and methodologically innovative, Playing to Win expertly captures the perspectives of parents and children regarding the importance of after-school activities for socialization and childhood in contemporary American society. Hilary Levey Freidman has produced a sociological gem."

-William A. Corsaro, author of The Sociology of Childhood

“Hilary Levey Friedman's Playing to Win is an essential social science volume that transcends the boundary between scholarship and popular critique. Levey Friedman successfully explains how upper-middle-class Americans think about their children's engagement in serious leisure: competitive chess, dance competitions, and youth soccer. Listening carefully to both parents and children, she reveals the tensions and contradictions, benefits and drawbacks of intense competitions, and provides a perspective necessary for researchers who examine child development and for parents who wish to raise happy, healthy children."

-Gary Alan Fine, author of With the Boys:

Little League Baseball and Preadolescent Culture and

Gifted Tongues: High School Debate and Adolescent Culture

"The world of twenty-first-century childhood has found its superb interpreter. With sparkling arguments and fascinating evidence, Hilary Levey Friedman's Playing To Win introduces us to one of America's most remarkable contemporary innovations: the proliferation of organized, competitive after-school activities. An important contribution to the sociology of culture and inequality."

-Viviana A. Zelizer, author of Pricing the Priceless Child: The Changing Social Value of Children

"Hilary Levey Friedman has managed to convince numerous uppermiddle-class parents and their children to pause in their mad dash between extracurricular activities to explain why they have chosen this lifestyle. Using information from detailed interviews across a variety of activities, she provides a revealing account of the motivations that lie behind the dramatic rise in competitive children's activities. This fascinating book forms a key part of an emerging body of research that links the increase in time devoted to childcare to parents' worries about their children's economic futures."

—Valerie Ramey, Professor and Chair of Economics, University of California, San Diego 
This page intentionally left blank 


\section{Playing to Win}

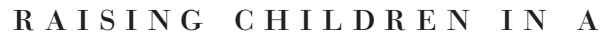

C O M P E T I T I V E C U L T U R E

H I L A R Y L E V E Y F R I E D M A N

무

U N IVERSITY OF CALIFORNIA PRESS

Berkeley Los Angeles London 
University of California Press, one of the most distinguished university presses in the United States, enriches lives around the world by advancing scholarship in the humanities, social sciences, and natural sciences. Its activities are supported by the UC Press Foundation and by philanthropic contributions from individuals and institutions. For more information, visit www.ucpress.edu.

University of California Press

Berkeley and Los Angeles, California

University of California Press, Ltd.

London, England

(C) 2013 by The Regents of the University of California

Library of Congress Cataloging-in-Publication Data

Friedman, Hilary Levey, 1980-

Playing to win : raising children in a competitive culture /

Hilary Levey Friedman.

pages $\mathrm{cm}$

Includes bibliographical references and index.

ISBN 978-0-520-27675-8 (hardback) — ISBN 978-0-520-27676-5

(paperback)

1. Competition (Psychology) in children. 2. Student activities.

3. After-school programs. 4. Sports for children. 5. Parenting.

6. Child development. I. Title.

$\mathrm{BF}_{723} \cdot \mathrm{C}_{6} \mathrm{~F}_{75} 2 \mathrm{O} 13$

$306.874-\mathrm{dc} 23$

2013021947

Manufactured in the United States of America

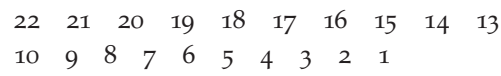

In keeping with a commitment to support environmentally responsible and sustainable printing practices, UC Press has printed this book on Rolland Enviro10o, a 100\% post-consumer fiber paper that is FSC certified, deinked, processed chlorine-free, and manufactured with renewable biogas energy. It is acid-free and EcoLogo certified. 
For my Family-

Past, Present, and Future 
This page intentionally left blank 